\title{
Pendekatan Ekperiensial untuk Meningkatkan Pemahaman Mata Ajar Nasionalisme
}

\author{
Agus Sediadi Tamtanus \\ Pusat Pendidikan Dan Pelatihan \\ Kementerian Riset Dan Teknologi/Badan Riset Dan Inovasi Nasional \\ agus@ristekbrin.go.id
}

\begin{abstract}
Abstrak
Penelitian menggunakan pendekatan eksperiensial melalui metode wawancara ini dapat meningkatkan pemahaman para peserta Latsar CPNS Golongan III secara signifikan. Semua aspek pembelajaran eksperiensial (experiential learning), yaitu: Aspek Rasa (Feeling), Aspek Pengamatan (Watching), Aspek Pemikiran (Thinking), dan Aspek Kegiatan (Doing) dapat terintegrasi dalam kegiatan wawancara. Metode kualitatatif menggunakan wawancara sudah menjadi trend suatu penelitian di masa sekarang ini, sebagai upaya mencari data primer untuk penelitian interpretif dan kritis. Hasil penelitian menunjukan adanya perubahan pola pikir (mindset) para peserta dalam memahami nasionalisme. Hasil analisa 2 (dua) angkatan yang melakukan wawancara, yaitu Angkatan III dan Angkatan IX, dimana pemahaman akan Nasionalis sangat erat kaitannya dengan Nilai-Nilai Panca sila (40\%), Cinta Tanah Air (26-35\%), dan lainnya hanya (25\%). Penilaian akan tingkat dan pemahaman seseorang tidak bisa dilakukan dalam waktu singkat dan sangat amat subyektif. Ini dikarenakan menyangkut rasa, hati dan pemikiran (sense, hart dan mindset). Diharapakan untuk para peserta yang telah mendapatkan pengalaman ini, yaitu pembelajaran eksperiensial pada saat mengikuti Latsar CPNS Golongan III, khsus mata ajar Nasionalisme, dapat mengimplementasikan Nilai-Nilai Pancasila dalam kesehariannya baik di kampus dan masyarakat dengan konsisten dan berkesinambungan.
\end{abstract}

Kata Kunci: Nasionalisme, Kuesioner, Wawancara

\section{Experiential Approaches to Enhance Understanding Nationalism Subject}

\begin{abstract}
This research used the experiential approach through the interview method could significantly increase the understanding of Latsar CPNS Group III participants. All aspects of experiential learning, including aspects of sense (feeling), aspects of observation (watching), aspects of thinking, aspects of activity are integrated into interview activities. Qualitative methods using interviews have become a trend of research in the present, as an effort to find primary data for interpretive and critical research. The results showed a change in mindset of the participants in understanding nationalism. The results of the analysis of 2 (two) classes conducting interviews, namely Class III and Class IX, where the understanding of the Nationalists is very closely related to the Five Values of Pancasila (40\%), Cinta Tanah Air (26-35\%), and others only (25\%). An assessment of a person's level and understanding cannot be done in a short time and is very subjective. This is because it involves feeling, heart and mind (sense, hart, and mindset). It is expected that the participants who have gained this experience, that is experiential learning while participating in the class of Latsar CPNS
\end{abstract}


Group III, specifically, Nationalism can implement Pancasila values in their daily lives both on campus and in the community with consistent and continous.

Keywords: Nationalism, Questionnaire, Interview

\section{PENDAHULUAN}

Tahun 2017, untuk pertama kalinya Pusat Pendidikan Dan Pelatihan Kementerian Riset, Teknologi, dan Pendidikan Tinggi (Pusdiklat, Kemeristekdikti) baru dapat menyelenggarakan kegiatan Pelatihan Dasar (Latsar) untuk para peserta Calon Pegawai Negeri Sipil (CPNS) Golongan III sesuai dengan tugas dan fungsinya yang tercantum dalam Permen Ristekdikti Nomor 15 Tahun 2015. Peserta adalah dosen dan tenaga pendidik dengan latar belakang lulusan Strata-2 dan Strata-3. Mata ajar yang diberikan untuk para peserta Latsar Golongan III, adalah: Mata ajar Akuntabilitas, Nasinonalisme, Etika Publik, Komitmen Mutu dan Anti Korupsi (ANEKA).

Sebagai salah satu fasilitator yang mengampu mata ajar nasionalisme mengalami kesulitan untuk dapat mengukur tingkat pemahaman para peserta. Bagaimana dan sejauh mana dapat mengukur hati seseorang akan tingkat pemahaman nasionlismenya. Sementara itu, menurut Suastika (2012), nasionalisme adalah jiwa dan semangat yang membentuk suatu kebersamaan tetapi realitasnya masih ada pasang surut rasa kebangsaan di masyarakat Indonesia sehingga dapat dikatakan belum mengakarnya nasionalisme di hati sanubari setiap anak bangsa.

Dalam beberapa tahun terakhir ini, merebak isu akan jiwa nasionalisme, sehingga saat ini menjadi perhatian khusus bagi bangsa Indonesia. Ini menggambarkan bahwa kondisi aktual kebangsaan sangat dipengaruhi oleh adanya Ancaman, Gangguan, Hambatan dan Tantangan (AGHT), baik dari internal maupun eksternal sehingga perlu adanya kewaspadaan yang tinggi yang akhirnya dapat membahayakan kedaulatan sebuah negara, keutuhan wilayah dan juga keselamatan seluruh dan segenap bangsa (Hendrastomo, 2007; Soedarmo, 2017; Kusumawardhana, 2017).

Gangguan nyata yang ada saat ini adalah masuknya era globalisasi, berdampak ke kedaulatan dan nasionalisme bangsa Indonesia, dimana adanya arus keterbukaan informasi dan pengaruh negatif asing dalam bentuk digitalisasi turut melemahkan kepribadian dan budaya Indonesia (Sediadi, 2018). Globalisasi tidak dapat dihindari, sehingga hubungan satu dengan yang lain dapat berlangsung dengan cepat dan tanpa disadari banyaknya budaya yang masuk sehingga memimbulkan berbagai masalah di negeri ini, seperti menurunnya rasa cinta budaya dan nasionalisme generasi muda. Untuk itu, seluruh lapisan masyarakat, khususnya generasi muda seluruh anak bangsa terus berusaha meningkatkan dan menumbuhkan akan rasa cinta akan budaya bangsa sejak usia (Agustin, 2011).

Adanya isu radikalisme yang merebak di masyarakat menjadikan perhatian khusus bagi bangsa ini, karena akan mengganggu dan mengusik rasa nasionalisme bangsa ini. Beberapa catatan dari Badan Intelijen Negara (BIN), yang cukup memprihatinkan adalah terpaparnya para mahasiswa mencapai angka 39\%, dari sejumlah perguruan tinggi dan berdasarkan wilayah ada 15 provinsi di Indonesia, bahkan tercatat ada tiga perguruan tinggi yang mendapat perhatian khusus, dikhawatirkan akan menjadi basis penyebaran paham radikal (Antaranews.com, 2018). 
Kecenderungan terjadinya penurunan pengetahuan dan pemahaman akan pentingnya jiwa nasionalisme di kalangan para dosen sebagai tenaga pendidik generasi mendatang akan berdampak pada sikap nasionalisme mahasiswa baik langsung ataupun tidak langsung, sehingga perlu ditelusuri dan ditindaklanjuti penyebabnya. Untuk itu, materi pembelajaran yang diberikan, salah satunya adalah Nasionalisme. Hal ini sesuai dengan tujuan pembelajaran, dimana setiap pegawai ASN wajib memiliki jiwa nasionalisme yang kuat dalam menjalankan fungsi dan tugasnya (Lembaga Administrasi Negara, 2015).

Berdasarkan adanya Peraturan Kepala Lembaga Administrasi Negara (LAN)

Nomor 21

Tahun 2016 tentang tata cara Penyelenggaran Pelatihan Dasar CPNS Golongan III, diberikan alokasi waktu 24 Jam Pembelajaran (JP) (Lembaga Administrasi Negara, 2016). Hasil belajar yang diharapkan, yaitu peserta mampu mengaktualisasikan Pancasila sebagai nilai-nilai dasar nasionalisme dalam pelaksanaan tugas jabatannya.

Pada saat pembelajaran di kelas, ada kecenderungan, peserta kurang fokus dan semangat pada saat masuk hari kedua. Ada beberapa faktor penyebanya, yaitu terjadinya kesulitan belajar (learning disabillites), seperti faktor intermal, antara lain minat, motivasi, tingkat intellegensia, sedangkan penyebab utama problema belajar (learning problems) adalah faktor eksternal, antara lain strategi pembelajaran, pengelolaan kegiatan pembelajaran, serta faktor lingkungan yang mempengaruhi prestasi belajar yang dicapai oleh siswa. Menurut Rahmayani (2019), guru atau fasilitator yag mempunyai peran penting dalam suatu pembelajaran, sehingga perlu adanya inovasi dan kreativitas dalam memberikanpembelajaran, sehingga harus mempunyai strategi pembelajaran yang baik dan menghindari teacher-centered, untuk menghidupkan suasana kelas. Menurut Bastian (2015), salah satu paradigma pembelajaran konstruktivisme di abad pengetahuan saat ini, aktivitas pembelajaran lebih mengutamakan aktivitas pebelajar dari pada aktivitas pengelola pembelajaran.

Untuk itu, strategi pembelajaran dirubah, dengan dengan menggunakan pendekatan pembelajaran eksperiensial (experiential learning), dimana peserta diberikan kesempatan untuk dapat lebih memperluas wawasannya akan nasionalisme melalui kegiatan wawancara dengan masyarakat di sekitarnya. Menurut Barida (2018), aktivitas peserta sangat penting dalam proses belajar mengajar, dimana ada beberapa karakteristik pembelajaran eksperiensial yang mencakup beberapa hal, yaitu: (1) Tindakan, dimana peserta dalam pembelajaran bukanlah partisipan yang menerima secara pasif, melainkan aktif, sekaligus adanya pergerakan fisik, dan tidak hanya duduk saja; (2) Refleksi, proses pembelajaran hanya terjadi setelah tindakan direfleksikan;

Fenomenologis, dimana kondisi lingkungan dapat diintepretasikan tanpa adanya suatu penilaian.

Pembelajar harus merasakan makna pada apa yang sedang berlangsung, dan makna fasilitator harus tidak secara otomatis memaksa terhadap peserta;

Pengalaman subjektif individu, sebagai nilai yang diterima bersama, bukan pandangan fasilitator semata, dan (5) Adanya pengalaman (eksperiensial) sebagai sumber pembelajaran.

Pembelajaran eksperiensial merupakan suatu upaya agar adanya suatu pengalaman manusia sebagai bagian dari proses pembelajaran. Ada beberapa faktor yang berkontribusi terhadap keberhasilan belajar, seperti faktor keaktifan bertanya, partisipasi dari mahasiswa selaku pembelajar, peran lingkungan sebagai media pembelajaran, dan dosen sebagai 
fasilitator. Melalui hubungan yang sinergis tersebut maka keberhasilan dalam suatu pembelajaran dapat tercapai secara optimal. Secara teoritis pembelajaran eksperiensial dapat mengenalkan peserta dengan lingkungannya, sehingga terjadi suatu interaksi peserta dengan lingkungan atau memberikan kesempatan kepada peserta untuk memperoleh lebih pengalaman.

Proses pengalaman belajar eksperiensial, terdiri dari: (a) Pengalaman belajar sehingga memperoleh pengalaman perasaan yang mengesankan (concrete experience/Feeling); (b) Pengalaman belajar sehingga dapat melakukan refleksi diri dengan baik dari hasil pengamatan(reflective

observation/Watching);

(c) Pengalaman belajar melakukan abstraksi konsep dari pemikiran yang ada dengan baik (abstract conceptualization/Thinking);

Pengalaman belajar melakukan tindakan dari ekperimen yang nyata (active experimentation/Doing).(Kolb,2005).

Gambar 1.

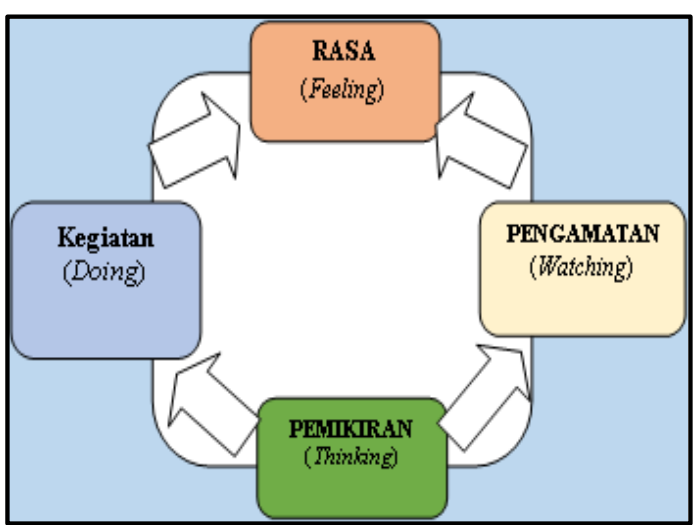

Gambar 1. Proses Pembelajaran Eksperiensial

Ada beberapa kelebihan penggunaan metoda wawancara ini, yaitu:

(1) Untuk dapat mencari data primer; (2) Untuk penelitian interpretif atau penelitian kritis, dan (3) Untuk menggali lebih dalam mengenai sikap, keyakinan, perilaku, atau pengalaman dari responden terhadap fenomena sosial; (4) Untuk dapat melakukan pertukaran informasi secara verbal dengan satu orang atau lebih, dan (5) Adanya peran pewancara untuk dapat menggali informasi dan pemahaman responden (Bastian, Winardi, \& Fatmawati, 2018).

Menurut Silverman (2011), saat ini kita hidup dalam era interview society, dimana ditandai dengan tersebarnya penggunaan metoda wawancara ini baik di ranah sosial, profesional, maupun akademik. Kekuatan wawancara di industri jurnalistik dan industri riset semakin nyata, dimana menjadi metode penelitian yang handal dan eksis dalam penelitian ilmu sosial (Gubrium \& Holstein, 2012).

Melalui wawancara mengasumsikan bahwa setiap orang memiliki kemampuan untuk berpendapat. Pemahaman dan penghayatan sesorang akan kondisi sosial akan berbeda satu dengan yang lain. Disisi lain, adanya wawancara merupakan akses mendapatkan informasi, tetapi proses proses wawancara tidak hanya bertanya saja atau berbagi informasi semata. Lebih jauh dalam proses ada fungsi, strategi dan taktik yang berkembang sesuai kebutuhan riset-riset utama. Pentingnya metoda wawancara dalam penelitian ini, karena mengukur ataupun mengevaluasi tingkat pemahaman sesorang akan nasionalisme sangatlah sulit, karena hal tersebut bagian dari rasa (sense) seseorang.

Kelebihan metoda wawancara, yaitu:

1) Digunakan dalam mencari data primer dan banyak dipakai dalam penelitian interpretif maupun penelitian kritis.

2) Metode wawancara dilakukan ketika peneliti ingin menggali lebih jauh akan sikap, keyakinan, 
perilaku, atau pengalaman dari responden terhadap fenomena sosial. Keunikan akan metoda ini, adalah terjadinya suatu pertukaran informasi secara verbal dari satu orang atau lebih.

3) Adanya tugas dan fungsi pewawancara yang berusaha untuk terus menggali informasi dari responden dan memahaminya.

4) Metode wawancara terlihat seperti sederhana namun sebenarnya begitu rumit.

5) Metoda wawancara berkembang secara dinamis sepanjang waktu. Kompleksitas akan metode wawancara bukan saja di aspek teknis semata tetapi di aspek epistemologisnya juga.

6) Metode wawancara terus berkembang tidak hanya sekedar dala bentuk komunikasi semata tetapi sudah menjadi semacam alat pertukaran produksi pengetahuan yang konstruktif diantara pewawancara dan responden.

7) Metode wawancara bisa dikatakan lebih dari sekedar alat.

8) Metode wawancara saat ini semakin berkembang jauh tidak hanya sekedar ilustrasi di atas tetapi wawancara kini lebih menekankan pada interaksi dengan responden.

9) Metode wawancara sudah dievaluasi ulang sehingga tidak ada lagi bentuk penggalian informasi yang monoton menjadi lebih interaktif, baik dalam struktur dan dinamikanya.

10) Ada perbedaan mencolok antara wawancara dengan percakapan biasa adalah adanya pemahaman mengenai peran adanya pewawancara dan peran responden. Apapun model dan bentuk wawancaranya, peran ini harus ditegaskan. Saat ini wawancara moderen bukan hanya berfokus pada jajaran elit saja, tetapi sudah ada perubahan bahwasanya setiap orang mempunyai pengetahuan dan pendapat yang dapat dijadikan sebagai responden (Bastian et al. 2018).

Dari ulasan tersebut, maka perlu adanya kegiatan pembelajaran yang lebih inovatif, sehingga efektif dan efisien dengan hasil yang maksimal. Penelitian ini dilakukan menggunakan pendekatan eksperiensial melalui metode wawancara untuk dapat melihat sejauh mana tingkat pemahaman mata ajar nasionalisme para peserta Latsar CPNS Golongan III.

\section{METODE}

Penelitian ini merupakan penelitian kualitatif, dimana sebagai responden adalah peserta Latsar CPNS Golongan III", Angkatan II dan Angkatan III (40 peserta) di Pusdiklat Serpong dan Angkatan VII dan Angkatan IX (38 peserta) di BPSDMD-Provinsi Jawa Tengah, tahun 2017.

Perlakuan ini diberikan berbeda, dimana ada angkatan yang tidak melalukan wawancara, yaitu Angkatan II \& VII dan yang melakukan wawancara Angkatan III \& IX, dimana diberikan waktu selama lebih kurang 4 JP untuk dapat melakukan kegiatan wawancara ke masyarakat di sekitarnya dan membuat tayangan dalam bentuk Video untuk melihat inovasi dan kreatifitas peserta.

\section{Wawancara}

1. Secara umum, diberikan pertanyaan yang sama untuk semua angkatan, yaitu: ada tulisan atau istilah atau kata "Nasionalisme", Apa yang ada di hati dan pemikiran anda?. Uraian para peserta dinilai berdasarkan katagori, dimana nilai $=1$ (tidak 
paham); 2 (cukup paham); 3 (paham); dan 4 (sangat paham).

2. Kuesioner (Quesionare) disampaikan secara daring (on line), pada bulan Desember 2019, dimana para peserta sudah menjadi PNS. Pertanyaan diberikan kepada Angkatan III dan Angkatan IX yang melakukan metode wawancara ke masyarakat disekitarnya.

Ada 5 (lima) pertanyaan sebagai Aspek Pembelajaran, yaitu:

1) Kegiatan melakukan wawancara yang dilakukan peserta langsung ke masyarakat di sekitarnya, akan menambah dan meningkatkan wawasan dan pemahaman akan nasionalisme;

2) Kegiatan melakukan wawancara yang dilakukan peserta langsung ke masyarakat di sekitarnya, mendapatkan pandangan yang beragam akan pemahaman arti nasionalisme;

3) Kegiatan melakukan wawancara yang dilakukan peserta langsung ke masyarakat di sekitarnya,mampu meningkatkan kerjasama dan tanggung jawab individu/kelompok;

4) Kegiatan melakukan wawancara yang dilakukan peserta langsung ke masyarakat di sekitarnya, dapat meningkatkan kompetensi dan kemampuan baik individu ataupun kelompok dalam merancang dan membuat video; dan

5) Kegiatan melakukan wawancara yang dilakukan peserta langsung ke masyarakat di sekitarnya, mampu meningkatkan kreativitas individu atau kelompok.
Peserta dapat memilih jawaban berdasarkan katagori, dimana nilai $=1$ (sangat kurang); 2 (kurang); 3 (cukup baik); 4 (baik); dan (sangat baik).

Data yang diperoleh hasil wawancara dalam bentuk rekaman dan disampaikan dalam transkrip.

\section{HASIL DAN PEMBAHASAN}

Hasil evaluasi wawancara dari ke empat angkatan pada saat di kelas, dapat dilihat pada Tabel 1 dan Tabel 2., dibawah ini:

Tabel 1. Hasil Wawancara Awal

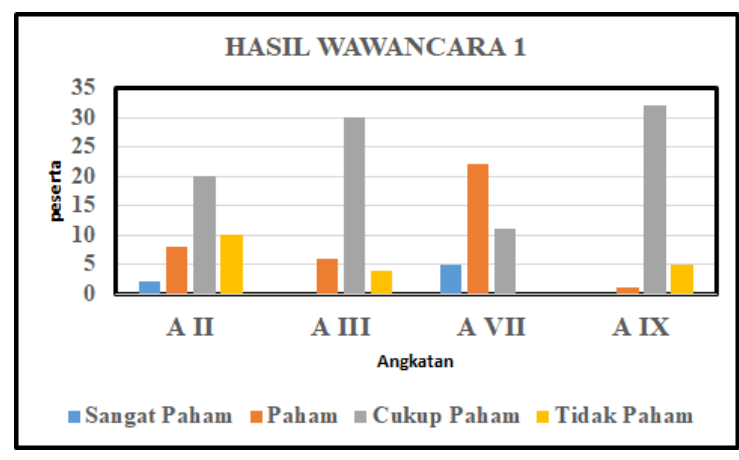

Tabel 2. Hasil Wawancara Akhir

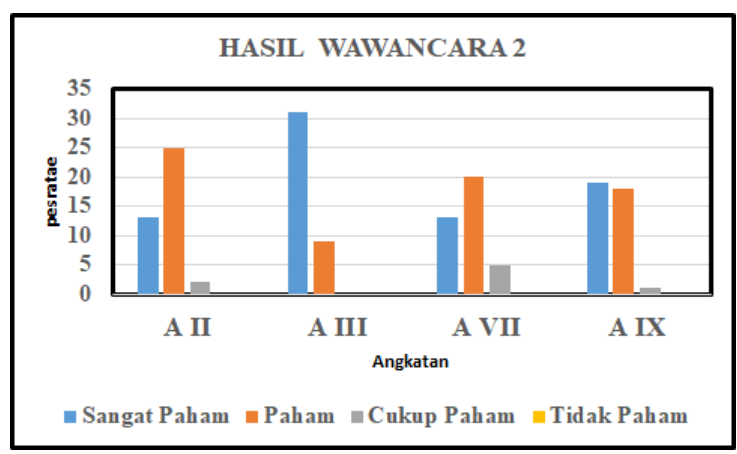

Wawancara di awal dan di akhir pembelajaran, diasumsikan sebagai bentuk pre-post test, dimana penilaian dalam bentuk katagori. Secara umum, ini memperlihatkan adanya peningkatan pemahaman peserta akan nasionalisme. Peningkatan pemahaman, dimana di Angkatan III tercatat capaian prosentase "sangat paham" mencapai 77,5\% dan "paham" 
22,5\%. Angkatan IX capaian prosentase "sangat paham" mencapai 47,5 \%; "paham" 45,0\% dan "cukup paham" $2,5 \%$.

Menurut Effendy (2016), hasil penelitiannya membuktikan siswa yang diberikan pre-post test mendapatkan nilai yang lebih tinggi dibandingkan siswa yang belajar dengan metode biasa tanpa adanya pre-post tes. Hasil adanya test awal dan akhir secara tidak langsung akan membantu terjadinya integrasi pengetahuan peserta sebelumnya dengan informasi yang baru sehingga bahan atau materi yang akan diajarkan dapat disesuaikan dengan kemampuan peserta, sehingga ada proses penyesuaian disisi kognisi (cognition accomodation), apabila materi belum dipahami oleh peserta. Secara teoritis, proses pembelajaran ada tiga tahapan, yaitu asimilasi, akomodasi dan equilibrasi (penyeimbangan). Proses asimilasi, yaitu upaya pengintegrasian informasi baru ke struktur kognitif yang ada dalam pikiran peserta, sehingga terjadi proses akomodasi dan penyesuaian struktur kognitif baru yang berkesinambungan antara asimilasi dan akomodasi (Lefa, 2014). Lebih lanjut, hasil penelitian Septiana et al. (2018), membuktikan juga nilai tes awal dan akhir dari kelas eksperimen lebih tinggi dari kelas kontrol. Hal ini dikarenakan ada proses pembelajaran berupa terjadinya proses komunikasi sehingga terjadi proses penyampaian pesan dari narasumber kepada penerima pesan.

Diharapkan dengan meningkatnya pemahaman nasionalisme peserta menjadi lebih baik mampu menahan arus globalisasi. Semangat nasionalisme yang tinggi masih sangat dibutuhkan oleh bangsa ini, seperti meningkatnya perilaku yang positif dan terbaik dimasyarakat, khususnya generasi muda. Untuk mengatasi masalah ini, perlu untuk memiliki gerakan yang intensif dan berkesinambungan dalam dunia pendidikan yang terkait dengan penanaman rasa nasionalisme terhadap siswa dari tingkat dasar hingga perguruan tinggi yang harus dilakukan oleh guru dan dosen dengan menghormati dan bangga dengan budaya asli Indonesia (Widiyono, 2019).

Ini harus menjadi pemikiran kita bersama bukan hanya dosen dan guru tetapi seluruh lapisan masyarakat. Adanya kekhawatiran, rasionalitas nasionalisme generasi milineal saat ini mengalami kemunduran bagi nilai-nilai kebangsaan, tetapi ini dikarenakan adanya perspektif yang berbeda pada nilai-nilai yang diperjuangkan, tetapi semangat dan kejiwaan nasionalisme tetap tertanam di kalbu mereka (Zam, 2018).

Ada ketercualian untuk para peserta Latsar Calon PNS Golongan III, walaupun mereka juga termasuk generasi milenial tetapi harus dapat mengimplementasikan rasa nasionalismenya itu kedalam kehidupan sehari-hari mereka, karena nasionalisme indikator penting sebagai nilai luhur dalam Pembukaan UUD 1945 dan Pancasila. Peserta latsar mempunyai tanggung jawab yang besar untuk dapat mewariskan nilai-nilai nasionalisme di sekitar mereka, karena dengan menanamkan sikap nasionalisme mereka bisa menjadi manusia pembangunan yang dapat mengisi dan mempertahankan kemerdekaan bangsa dan negaranya. Untuk mencapai tujuan dan sasaran tersebut maka perlunya dilaksanakan pelatihan dasar sehingga adanya proses pembinaan, pengembangan dan pendewasaan peserta (Permata \& Anita, 2012).

Maraknya isu radikalisme yang berkembang di berbagai perguruan tinggi harus dicermati dengan seksama. Menurut Fadli \& Barata (2018), hasil penelitian mereka membuktikan bahwa 
kerangka paradigmatik para dosen Pendidikan Kewarganegaraan (PKn) di Universitas Jember (UNEJ) dan IKIP PGRI Jember dikaitkan dengan nasionalisme berada pada posisi yang menguatkan dan tidak ada yang berorietasi untuk merobohkan sendisendi kebangsaan Indonesia. Mereka sepakat dan mendukung sepenuhnya akan keberadaan Pancasila, UUD 1945, NKRI, dan Bhinneka Tunggal Ika, sebagai suatu pilihan yang tepat dan final. Untuk itu, perlu adanya formulasi mata kuliah PKn yang ideal dalam mempertegas nilai Nasionalisme. Langkah-langkah yang perlu disiapkan, seperti adanya penataan kurikulum, adanya seleksi dosen secara ketat yang akan mengampu mata kuliah PKn tersebut. PKn tidak hanya menjadi pengetahuan dengan idealitas teori belaka, akan tetapi PKn harus dijadikan mata kuliah yang aplikatif dalam menyelesaikan problem kebangsaan kontemporer.

Sementara itu Hikmah \& Cholisisn (2017), menyampaikan hasil penilitiannya bahwa implementasi nasionalisme ada 2(dua) katagori, yaitu: (1) Cinta Tanah Air yang digambarkan seperti lunturnya nasionalisme, kurangnya partisipasi aktif masyarakat, dan sikap tolerasi; $\begin{array}{ll}\text { dan } & \text { (2) Terjadinya }\end{array}$ proses transformasi nasionalisme yang digambarkan seperti ketauladanan, disiplin dan kebersihan lingkungan, dimana masing-masing katagori mempunyai hambatan yang cukup kuat seperti globalisasi dan kurangnya tauladan kepada peserta didik.

Nampaknya, hasil penelitian ini memberikan kazanah, bahwasanya dalam implementasi nasionalisme ada 3 (tiga) katagori, yang secara keseluruhan merubah mindset para peserta Latsar Golongan III, yaitu: 1) Mampu mengimplementasikan nilainilai Pancasila; 2) Cinta Tanah Air; dan
3) Lainya (rela berkorban, gotong royong, kerja keras dll.), seperti Tabel 3 , di bawah ini.

Tabel 3. Perubahan Mindset

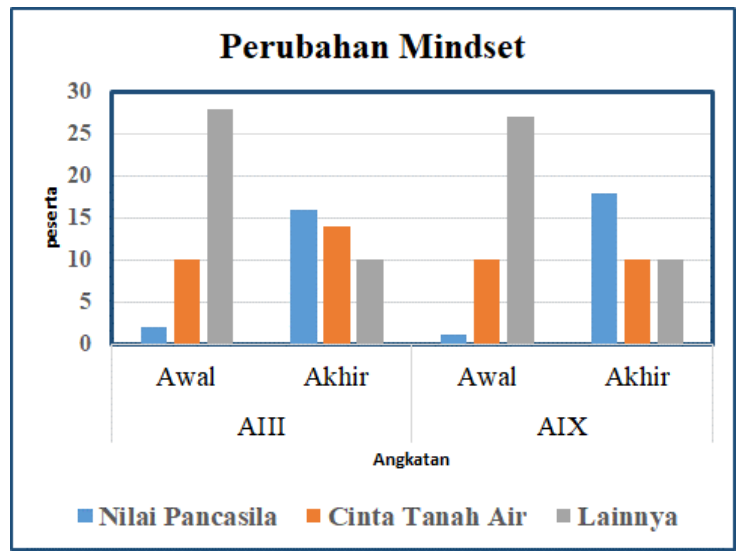

Lebih lanjut. pertanyaan di sebarkan dalam bentuk kuesioner secara on line, tercatat 33 lembar kembali. Hasil uji validitas dan reabilitas ke 5(lima) pertanyaan tersebut valid dan reliabel (nilai $R_{\text {tabel }}=$ $0,344(0,05 ; \mathrm{DF}=33-2=31)$. Hasil jawaban ke 5(lima) pertanyaan tersebut, dapat dilihat pada Tabel 4 , di bawah ini:

Tabel 4. Jawaban Pertanyaan dari Peserta

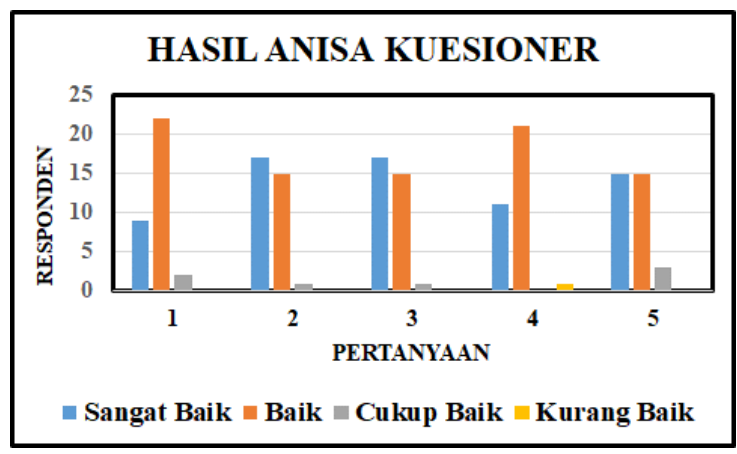

Pertanyaan yang dijawab oleh responden masuk dalam katagori "sangat baik" adalah pertanyaan nomor 2 (dua), tercatat 17 responden dan pertanyaan nomor 3 (tiga), masuk katagori "baik", tercatat 
17 responden. Pertanyaan nomor 2 (dua), yaitu: Apakah dengan melakukan kegiatan wawancara langsung ke masyarakat di sekitarnya, peserta akan mendapatkan pandangan yang beragam akan pemahaman arti nasionalisme?. Jawabnya: Ya.

Hasil ini cukup beralasan, karena cevitas akademika di kampus dipresepsikan masyarakat seperti menara gading yang sulit berinteraksi diluar lingkungannya. Sementara, menurut Alfaruqy \& Masykur (2014), pembentukan karakter nasionalisme di presiden mahasiswa masih diperlukan adanya interaksi dan pengaruh orang lain yang dianggap penting, seperti orang tua, teman, dan dosen.

Selanjutnya, pertanyaan di nomor 3 (tiga), yaitu: Apakah dengan melakukan kegiatan wawancara langsung ke masyarakat di sekitarnya, peserta mampu meningkatkan kerjasama dan tanggung jawab individu/kelompok?. Jawabnya: Ya. Dilihat dari hasil analisis nilai Alpha Cronbach's, pertanyaan nomor 3 memiliki nilai paling tinggi, sehingga dari kelima pertanyaan yang diajukan menjadi pertanyaan yang paling relevan kaitannya dengan "nasionalisme". Dalam modul nasionalisme, ditekankan untuk dapat mengimplemtasikan nilai-nilai Pancasila, khusunya oleh seorang ASN dalam perilaku kesehariannya. Ini menjadi outcome, yang harus tercapai, seperti mempunyai rasa tanggung jawab yang tinggi. Hal ini, ada di Sila Ke 1, yaitu: Ketuhanan Yang Maha Esa dan gotong royong (bekerjasama) dan ada di Sila Ke 3, yaitu: Persatuan Indonesia.

Selanjutnya, menurut Winarno, (2013), idiologi Pancasila masih kuat diyakini oleh para mahasiswa. Permasalahannya, adalah metode pembelajarannya yang sering tidak sesuai dengan kompetensi yang diukur.
Untuk itu, pentingnya PKn untuk para mahasiswa maupun dosen sebagai warga negara agar lebih dapat memahami kehidupan pribadi, sosial, budaya, ekonomi, pertahanan dan keamanan bangsa dan negaranya. PKn harus diberikan secara utuh, sehinga tidak ada saling tumpang tindih dengan disiplin ilmu lainnya, karena permasalahan pendidikan patriotisme terletak pada persepsi dan pendefinisian yang sangat bervariasi (Nurdin \& Dahliyana, 2017).

Menurut Sumardi et al. (2017), masih banyak mahasiswa yang mengikuti PKn (Civic Education) yang malas, hedonis, instan dan rendahnya kesadaran perlunya membangun struktur mental dan karakter yang mulia. Untuk menjadi perhatian bagi para dosen, khususnya dosen PKn yang mengikuti Latsar CPNS Golongan III. Diharapkan melalui PKn, dapat mendorong para mahasiswanya mempunyai pemikiran ilmiah, sikap dan karakter yang baik dalam kehidupan sehari-hari.

Lebih lanjut, akan di bahas data hasil wawancara langsung 5 peserta alumni Latsar CPNS Golongan III yang pernah melakukan kegiatan wawancara ke masyarakat pada saat pembelajaran nasionalisme. Keterbatasan responden dikarenakan adanya epidemi Covid-19. Peserta saat ini sudah menjadi PNS. Analisis hasil wawancara dikaitkan dengan teori pendekatan eksperiensial, dimana dikelompokan dalam 4 tahapan, yaitu kelompok tahap Pemikiran (Thinking), Rasa (Feeling), Kegiatan (Doing) dan Pengamatan (Watching). Hal ini sesuai bahwasanya salah satu metode kualitatif, yaitu: melakukan wawancara, dimana peneliti harus mempersiapkan dengan baik sehingga proses penelitian dapat berjalan optimal. 
Berdasarkan atas hasil penelitian ini, maka dapat diuraikan hal-hal sebagai berikut:

\section{Tahap Pemikiran dan Rasa.}

Peserta mendapatkan umpan balik (feedback) dari responden sangat beragam dan cukup mengejutkan. Implementasi nasionalisme dalam pemikiran dan rasa dari para responden, adalah tetap semangat mempertahankan kemerdekaan, menjaga keutuhan bangsa, mengembalikan kembali kegiatan gotong royong yang dirasakan sudah menurun, meningktakan rasa peduli antar sesama dan aktif mengikuti kegiatan di lingkungan dan sekitar masyarakatnya, rasa kebangsaan untuk menjaga Bhineka Tunggal Ika.

Pemikiran dan rasa kekhawatiran akan adanya bahaya laten PKI masih ada dalam masyarakat. Adanya pernyatan yang cukup heroik dari responden, dimana siap membalas jika ada serangan dan ancaman dari PKI, dan menghimbau agar generasi muda saat ini harus tetap meningkatkan kewaspadaanya yang dirasakan sudah mulai terlupakan.

Adanya pandangan yang berbeda dari responden, dimana dinilai bahwasanya kondisi nasionalisme di masyarakat masih baik, tetapi ada juga yang merasa terganggu dan sangat mengkhawatirkan. Hal ini dikarenakan masih adanya kelompok yang saling mau menang sendiri dan meningkatnya arogansi. Disisi lain, dirasakan menurunnya dan berkurangnya tingkat kerukunan di masyarakat, seperti maraknya tawuran di berbagai daerah.

Responden ternyata mempunyai pengetahuan yang cukup baik, dimana mengungkapkan rasa khawatirnya akan dampak globalisasi yang melanda Indonesia, kalau tidak ada kepedulian masyarakat ini akan menjadi salah satu sumber pengikisan nilai-nilai nasionalisme, sehingga ada kecenderungan bahwa budaya dari luar itu lebih bagus.

Merebaknya berita palsu (Hoax) melalui media sosial dalam bentuk tulisan, foto dan video menjadi pemikiran responden juga. Kerisauan responden akan maraknya pemakaian dan pasokan narkoba saat ini menjadi salah satu faktor yang dapat menghancurkan ketahanan nasional bangsa dan negara Indonesia. Permasalahan yang harus mendapatkan perhatian, menurunnya etika dikalangan remaja, sikap kesopanan terhadap orang tua, tingkat kejujuran dan merebaknya tindak pidana korupsi.

Responden, seorang gadis milinial menyatakan, yaitu nasionalisme generasi muda saat ini mulai menurun, dimana nasionalisme yang ada dan ditampilkan menurutnya adalah sebuah pencitraan semata melalui media sosial!. Seorang ibu, mengatakan nasionalisme adalah rasa cinta Indonesia, dan menurutnya generasi muda saat ini cukup nasionalis. Ini menjadi catatan penting, masih adanya secercah optimesme di hati masyarakat. Memang tidak bisa digeneralisasi, karena banyak faktor disekitar kita. Sementara itu, ada beberapa persepi responden yang cukup baik, yaitu mengejawantahkan arti "nasionalisme" tidak hanya cinta tanah air saja tetapi sudah implementatif dalam kehidupan keseharian mereka, seperti: melaksanakan tugas secara profesional; menghargai pendapat orang lain, dan memberikan pelayanan prima.

Hal yang sangat baik, walaupun hanya seorang satpam, dia mengutarakan bahwa nasionalisme adalah suatu "Kepribadian yang menuju kenegaraan", dimana harus mau berkorban untuk negara dan proaktif untuk siap membantu di 
lingkungan masyarakat sekitarnya. Sesuatu pemikiran yang sangat luar biasa untuk seorang remaja SMA. Salah satu kelemahan bangsa dan masyarakat Indonesia adalah tidak mau atau kurang belajar akan sejarahnya, dimana bangsa yang besar adalah bangsa yang memahami perjalanan sejarahnya. Masalah yang ada cenderung seperti lingkaran setan tidak pernah dapat diselesaikan dengan baik.

Beberapa masukan dari responden di atas, menjadi tambahan wawasan akan arti "nasionalisme" yang nyata di masyarakat yang mungkin tidak tersampaikan di kelas.

Pengalaman (ekspiensial) yang sangat berarti bagi peserta Latsar, yang seharusnya menjadi pemikiran dan olah rasa para peserta Latsar ini, dimana harusnya dapat ditindak lanjuti untuk perbaikan bangsa dan negara yang nota bene mereka adalah seorang dosen dan salah satu ujung tombak sebagai agen perubahan (agent of change) untuk dapat memperbaiki keadaan ini menjadi lebih baik.

Tingkat

pemahaman

nasionalisme para dosen ini sudah baik, tetapi kurikulum saat ini belum jelas. Menurut Dahliyana et al. (2018), dari hasil penelitiannya para mahasiswa menganggap penting adanya mata kuliah PKn $(98,19 \%)$ tetapi dirasakan ketidak jelasan dengan mata kuliah lainnya $(96,98 \%)$, disisi lain para mahsiswa berharap penyampaian materi awal PKn ini harus dapat disampaikan dengan baik dan jelas $(19,4 \%)$. Jadi kedudukan PKn sebagai mata kuliah yang diberikan harus mampu terintegrasi dengan materi nasionalisme, dan materi budi pekerti (Cahyanti, 2016), karena sebetulnya sudah terdapat korelasi antara mata kuliah PKn dengan pengetahuan kewarganegaraan (civic knowledge) di mahasiswa FKIP Untirta (Raharja, et al. 2017).
Dosen adalah seorang ASN yang harus mempunyai wawasan nasionalisme yang tinggi, karena akan menjadi panutan mahasiswanya di kampus. Sosok panutan yang baik akan berupaya terus meningkatkan kepeduliannya sosial di lingkungannya. Kepedulian para dosen di kampus, terhadap para mahasiswanya, yaitu: secara berkesinambungan dan aktif mengingatkan para mahasiswanya untuk dapat menghindari kegiatankegiatan yang mendorong radikalisme; harus lebih aktif berinteraksi dan berkomunikasi dengan seluruh mahasiswanya, tanpa melihat fakultasnya pada setiap kesempatan (Sediadi, 2018).

Dosen berperan sangat penting dalam mengembangkan dan mendidik karakter di kampus (Bali, 2013). Persoalan nasionalisme adalah persoalan anak bangsa, bukan persoalan orang perorangan atau persoalan para pejabat saja. Diharapkan nasionalisme bukan hanya jargon atau dongeng semata tetapi perlunya adanya tindakan nyata untuk mepertahankan dan meningkatkan implementasi nasionalisme oleh masyarakat dan semua lembaga yang ada. Jadi untuk menjadi suatu bangsa yang besar adalah bangsa yang seluruh lapisan masyarakatnya sangat peduli dengan negaranya (Jemmy, 2016).

\section{Tahap Pengamatan dan Kegiatan.}

Pada tahap ini, fokus pada kompetensi para peserta. Apa yang dimaksud dengan istilah kompetensi?. Sesuatu hal yang indikatornya dilandasi oleh adanya kemampuan akan pengetahuan dan wawasan sesorang yang menjadi acuan dalam melaksanakan pekerjaannya sebagai petugas atau pegawai.

Di tahap pengamatan dan kegiatan, yang dilihat adalah kompetensi kelompok, dimana peserta, 
ditugaskan oleh fasilitator untuk membentuk kelompok dan persiapan untuk melakukan kegiatan wawancara ke masyarakat di lingkungan sekitar kampus Pusdiklat. Nampaknya pada tahapan koordinasi di kelompok peserta agak kesulitan, yaitu untuk memilih dan menentukan pimpinan kelompok. Kendala psikologis dikarenakan masih adanya perasaan terkotak-kotak berdasarkan latar belakang pendidikan dan asal perguruan tinggi. Ditahapan inilah peserta sudah mampu mengamati rekan kelompoknya untuk disepakati menjadi pimpinan kelompok.

Selanjutnya, pembentukan kelompok ditentukan oleh fasilitator, membentuk 3/4 (tiga/empat) kelompok, dengan anggota 8-10 orang. Langkah berikutnya, peserta secara mandiri melakukan koordinasi.

Kata koordinasi mudah diucapkan dan sesuatu yang nampaknya mudah, tetapi sesuatu yang cukup sulit dilaksanakan. Hal ini memperlihatkan bahwa untuk melakukan berkoordinasi juga perlu mempunyai pengalaman dari masingmasing individu yang cukup. Pembagian tugas dilakukan di masingmasing dikelompok, yaitu adanya pembagian tugas dan peran, tim pewancara, tim perekam kegiatan, dan tim editing untuk dapat bekerjasama dengan intens dengan penuh tanggung jawab.

Pengalaman dilapangan setiap individu/kelompok tidak sama tetapi semua merasakan adanya kendala. Contoh, kegagalan sesorang tim pewancara untuk melakukan wawancara dengan responden. Hal ini, menjadi catatan bahwasanya melakukan pendekatan ke masyarakat juga diperlukan adanya pengalaman dan strategi (waktu, sasaran dan pendekatan).

Pengalaman yang peserta dapatkan ini, seperti belajar kooperatif dan berimpati akhirnya menjadikan secara langsung atau tidak langsung adanya peningkatan kemampuan individu di masa mendatang.

Melakukan kegiatan wawancara dengan masyarakat harus dipersiapkan dengan baik perlu adanya kreativitas dan kompetensi yang cukup baik. Dampak kompetensi lain yang didapatkan adalah pemanfaatan Teknologi Informasi dan Komunkasi (TIK) meningkat, khususnya pemanfaatan gadget secara maksimal.

$\begin{array}{rrr}\text { Beberapa jawaban peserta, } \\ \text { ungkapan } & \text { pertama } & \text { yang }\end{array}$ disampaikannya adalah kegiatan melakukan wawancara langsung dengan masyarakat sesuatu hal yang sangat menyenangkan. Kesempatan untuk dapat bisa terjun ke lapangan dan berinteraksi langsung dengan masyarakat dan menambah pengalaman peserta.

Terjadinya interaksi langsung dengan masyarakat, diharapkan peserta dapat mengenal masyarakat disekitarnya selama mengikuti pelatihan mengetahui kondisi ataupun keadaan masyarakat secara langsung. Ini diharapkan nantinya menjadi habituasi para peserta setelah kembali ketempat tugasnya masing-masing, sehingga mereka akan dapat mengenal lingkungan sekitarnya lebih intens dalam berkomunikasi, seperti dengan penjaga parkir, keamaanan, dan kebersihan (office boy).

Hal ini sangat penting, karena peserta adalah para dosen yang bertanggung jawab mendidik generasi muda sebagai penerus bangsa yang kedepannya menjadi agen perubahan, sehingga tidak lingkungan kampus bukan suatu lingkungan seperti di menara gading tetapi lingkungan akademisi yang dapat terbuka berkomunikasi dengan masyarakat sekitarnya. 
Pernyataan dari peserta yang cukup mengejutkan adalah pembelajaran di kelas cukup menjenuhkan dan membosankan, dimana dirasakan untuk 1 mata ajar Nasionalisme saja memerlukan waktu 24 JP saat itu. Adanya kegiatan menggunakan metode wawancara, para peserta menyatakan pembelajaran yang menyenangkan. Peserta juga memberikan pernyataan bahwa metode wawancara yang mereka lakukan dapat membantu untuk lebih mengenali permasalahan langsung di lapangan, serta dapat mencari penyeselsaiannya peremasalahan tersebut langsung dari sumbernya, khusus masalah Nasionalisme.

Pembelajaran dirasakan lebih aplikatif, dimana dirasakan belajar dikelas hanya berdasarkan teori semata (text book). Hasil wawancara peserta terhadap masyarakat di lingkungan sekitar dengan berbagai latar belakang umur, kelamin, pendidikan dan profesi ternyata masyarakat cukup memahami akan arti nasionalisme. Walaupun responden tidak berpendidikan tinggi tatapi memberikan input yang sangat baik dan realistis, bahkan inputnya lebih baik dari pemikiran para peserta. Sebagai contoh: nasionalisme diartikan sesuatu tindakan simple yang sesuai undang-undang yang ada, berkendaraan harus taat aturan dan warganegara harus bayar pajak.

Para peserta dari kelompok yang ada berlomba dalam pembuatan video dan mengeluarkan krativitasnya semaksimal mungkin, sehingga terjadi persaingan yang sehat. Kejenuhan yang peserta rasakan dikelas, disibtusikan ke kegiatan yang mereka anggap menyenangkan dengan berkoordinasi dan berkuminaksi lebih intens dalam suasana informal sehingga tanpa disadari menumbuhkan tanggung jawab dan meningkatkan kerjasama yang sangat baik.
Secara umum para peserta dengan melakukan kegiatan wawancara ini merasakan adanya pengalaman baru, hasil belajar di luar kelas yang mempunyai makna, dalam arti terdapat proses yang dapat dikaitkan adanya informasi baru dan konsep-konsep yang relevan dalam struktur kognitif seseorang (Nursalam et al., 2019). Jajang (2018), menekankan bahwa ada perbedaan signifikan antara metode ceramah dan visitasi, dimana hasil nilai rata-rata dengan metode visitasi lebih tinggi daripada metode ceramah. Menurut Latipah (2017), secara teoristis self regulated learning memiliki peranan yang sangat penting terhadap banyak aspek kehidupan terutama bidang akademik, hal ini membuktikan adanya strategi experiential learning dapat meningkatkan self regulated learning mahasiswa.

Disisi lain, berdasarkan hasil penelitian menunjukkan adanya dampak yang signifikan dari pengalaman belajar (experiential learning), pada memperoleh pengetahuan dan dapat mengembangkan keterampilan sosial dan sikap siswa, tetapi berkontribusi pada promosi warisan budaya dan nilai-nilai tradisi (Voukelatou, 2019). Selain itu, menurut Arseven, (2018), adanya konsistensi antara teori experiential learning tentang pembelajaran dan paradigma studi kasus kualitatif adalah konsisten dengan kerangka prinsipnya seperti subjektivitas, interaksi lingkungan, holisme, kontekstualitas, konstruktivisme, dan akses ke informasi.

Metode wawancara yang telah dilaksanakan oleh peserta Latsar Golongan III ini, akan mendorong juga terwujud komitmen mutu seorang 
dosen, karena wujud komitmen mutu seorang dosen, mencakup aspek rasa tanggung jawab dalam pengajaran, adanya kreativitas, budaya kerja yang kondusif dan kerjasama antar dosen (Asih, 2019).

\section{KESIMPULAN}

Penelitian menggunakan pendekatan eksperiensial melalui metode wawancara ini dapat meningkatkan pemahaman para peserta Latsar CPNS Golongan III secara signifikan. Semua aspek pembelajaran eksperiensial (experiential learning), yaitu: Aspek Rasa (Feeling), Aspek Pengamatan (Watching), Aspek Pemikiran (Thinking), dan Aspek Kegiatan dapat terintegrasi dalam kegiatan wawancara.

Metode kualitatif menggunakan wawancara sudah menjadi trend suatu penelitian di masa sekarang ini, sebagai upaya mencari data primer untuk penelitian interpretif dan kritis.

Hasil penelitian menunjukan adanya perubahan mindset para peserta dalam memahami nasionalisme. Penilaian akan tingkat dan pemahaman seseorang tidak bisa dilakukan dalam waktu singkat dan sangat amat subyektif. Ini dikarenakan menyangkut rasa, hati dan pemikiran (sense, hart dan mindset).

Diharapakan untuk para peserta yang telah mendapatkan pengalaman ini, yaitu pembelajaran eksperiensial pada saat mengikuti Latsar CPNS Golongan III, khsus mata ajar Nasionalisme, dapat mengimplementasikan nilai-nilai Pancasila dalam kesehariannya baik di kampus dan masyarakat dengan konsisten dan berkesinambungan.

\section{DAFTAR PUSTAKA}

Alfaruqy, M. Z. \& A. . M. (2014). Memaknai Nasionalisme: Studi
Kualitatif Fenomonologi pada Presiden Mahasiswa Perguruan Tinggi Negeri di Jawa Tengah dan Daerah Istimewa Yogyakarta. https://doi.org/10.1017/CBO9781 107415324.004.

Antaranews.com. (2018). BIN katakan 39 persen mahasiswa terpapar radikalisme - ANTARA News. Retrieved May 10, 2018, from https://www.antaranews.com/berit a/705555/bin-katakan-39-persenmahasiswa-terpapar-radikalisme.

Arseven, I. (2018). The use of qualitative case studies as an experiential teaching method in the training of pre-service teachers. International Journal of Higher Education, 7(1), 111-125. https://doi.org/10.5430/ijhe.v7n1p 111.

Asih, S. (2019). Mengawal Komitmen Mutu Dosen Perguruan Tinggi. Jakarta.

Bali, M. M. (2013). Peran Dosen dalam Mengembangkan Karakter Mahasiswa. Humaniora, 4(45), 800-810.

Barida, M. (2018). Model Experiential Learning dalam Pembelajaran untuk Meningkatkan Keaktifan Bertanya Mahasiswa. Jurnal Fokus Konseling, 4(2), 153. https://doi.org/10.26638/jfk.409.2 099

Bastian, A. (2015). Reorientasi paradigma pembelajaran konstruktivisme dan profesionalisme dosen untuk meningkatkan mutu lulusan dalam abad pengetahuan. Lectura Jurnal Pendidikan, 6(2).

Bastian, I., Winardi, R. D., \& Fatmawati, D. (2018). Metoda Wawancara. Metoda Pengumpulan Dan Teknik Analisis Data, (September 2018), 53-99.

Cahyanti, N. (2016). Hubungan Antara Budi Pekerti Dengan Hasil 
Belajar PKn Siswa Kelas V SD Negeri Di Kecamatan Sukoharjo. UNNES.

Effendy, I. (2016). Pengaruh pemberian pre-test dan post-test terhadap hasil belajar mata diklat hdw.dev.100.2.a pada siswa smk negeri 2 lubuk basung. Jurnal Ilmiah Pendidikan Teknik Elektro, 1(2), 81-88.

Fadli \& Barata. (2018). Urgensitas Paradigma Dosen Pendidikan Kewrganegaraa Dalam Mempertegas Nasionalisme. UCEJ, 3(2), 183-205. Retrieved from

http://jurnal.untirta.ac.id/index.ph p/UCEJ/article/view/4537/3256

Gubrium, J. F., \& Holstein, J. A. (2012). Narrative practice and the transformation of interview subjectivity. The SAGE Handbook of Interview Research: The Complexity of the Craft, (February), 27-44. https://doi.org/10.4135/97814522 18403.n3

Hikmah dan Cholisisn. (2017). Pembelajaran Pendidikan Kewarganegaraan Sebagai Proses Transformasi Nasionalisme Di Kalangan Siswa (Studi Deskriptif di SMAIT Abu Bakar Yogyakarta). Jurnal Pendidikan Kewaraganegaraan Dan Hukum, 6(4), 740-753.

Jajang, S. (2018). Perbedaan Hasil Belajar Metode Ceramah Dengan Visitasi Pada Mata Pendidikan Dan Pelatihan Wawwasan Kebangsaan. Jakarta.

Jemmy, S. (2016). Nasionalisme Retorika Gombal Meneropong Indonesia dari sudut orang muda. PT.Elex Media Komputindo.

Kolb, A. Y. K. and D. A. (2005). Learning Styles and Learning Spaces: Enhancing Experiential Learning in Higher Education.
Academy of Management Learning \& Education, 4(2), 193212.

LAN. (2016). Peraturan Kepala Lembaga Administrasi Negara Nomor 21 Tahun 2016. Pedoman Penyelenggaraan Pelatihan Dasar Calon Pegawai Negeri Sipil Golongan Iii, 1-96. Retrieved from http://sister.lan.go.id/documents/6 25872/1525062/Peraturan+Kepala +LAN+Nomor+21+Tahun+2016+ tentang+Pedoman+Penyelenggara an+Pelatihan+Dasar+Calon+Pega wai+Negeri+Sipil+Golongan+III/ e545d114-95b0-4cb2-97bef57f92fa6744? version $=1.2$

Latipah, E. (2017). Pengaruh Strategi Experiential Learning Terhadap Self Regulated Learning Mahasiswa. Humanitas, 14(1), 41. https://doi.org/10.26555/humanita s.v14i1.4547.

Lefa, B. (2014). The Piaget theory of cognitive development: An educational implications. Research Gate, 1(9), 1-9. Retrieved from https://www.researchgate.net/publ ication/252532772_Constructing a_theory_of_learner_autonomy_S ome_steps_along_the_way

Lembaga Administrasi Negara. (2015). "NASIONALISME" Modul Pendidikan dan Pelatihan Prajabatan Golongan III. LAN. https://doi.org/10.1017/CBO9781 107415324.004

Nurdin, E.S. \& A. Dahliyana. (2017). Civic Education as Patriotism Education in Indonesia. In Proceedings ofthe 2nd International Conference on Sociology Education (ICSE 2017) (Vol. 1, pp. 427-431). https://doi.org/10.5220/00070996 04270431

Nurdin, E.S \& Asep Dahliyana. (2018). 
Pendidikan Kewarganegaraan Berbasis Pembinaan Nasionalisme dan Patriotisme. (D. Budimansyah, Ed.). Bandung: CV. Maulana Media Grafika.

Nursalam, L. O., Harianto, E., Hasan, M., \& Sejati, A. E. (2019). NilaiNilai Dalam Aktualisasi Peningkatan Karakter Kepedulian Lingkungan Mahasiswa. Jurnal Tunas Geografi, 08(02), 151-160.

Permata, R. V. \& A. T. (2012). Model Pembelajaran Nasionalisme Project Citizen Pada Pendidikan Kewarganegaraan Sekolah Menengah Atas Untuk Mewujudkan Karakter Cinta Tanah Air Kepada Peserrta Didik. UNS. Retrieved from https://eprints.uns.ac.id/id/eprint/1 2648

Raharja, RM., W. H. L. \& D. S. . (2017). PengaruhPembelajaran Pendidikan Kewarganegaraan Terhadap Kompetensi Warga Negara Mahasiswa FKIP UNTIRTA. UCEJ, 2(1), 199-213.

Rahmayani, A. L. (2019). Pengaruh Model Pembelajaran Discovery Learning dengan Menggunakan Media Video Terhadap Hasil Belajar Siswa. Jurnal Pendidikan (Teori Dan Praktik), 4(1), 59. https://doi.org/10.26740/

jp.v4n1.p59-62

Sediadi Tamtanus Agus. (2018). Pemikiran: Menetralisir Radikalisme Di Perguruan Tinggi Melalui Para Dosen (Studi Kasus Diklat Prajabatan Golongan III Tahun 2016, Kementerian Riset, Teknologi, dan Pendidikan Tinggi). UCEJ, 3(2), 206-223.

Septiana, M. M. et al. (2018). Effectiveness of Local History Module Based on Inquiry to Improve the Learning
Achievement of High School Students. Jurnal Pendidikan Dan Pembelajaran, 25(1), 1-7. Retrieved from http://journal2.um.ac.id/ index.php/jpp/article/view/9906

Silverman, D. (2011). Interpreting Qualitative Data A Guide to the Principles of Qualitative Research (5th ed.). Los Angeles: SAGE.

Sumardi, L., Rispawati, \& Ismail, M. (2017). The Effect of Information Technology on Learning ( A Study on Civic and Pancasila Education Students at Mataram University ). Jurnal Pendidikan Dan Pembelajaran, 24(2), 73-78. Retrieved from http://journal2.um.ac.id/index.php /jpp/article/download/6827/3448

Voukelatou, G. (2019). The contribution of experiential learning to the development of cognitive and social skills in secondary education: A case study. Education Sciences, 9(2). https://doi.org/10.3390/educsci90 20127.

Widiyono, S. (2019). Pengembangan Nasionalisme Generasi Muda di Era Globalisasi. Populika, 7(1), 12-21.

Winarno. (2013). Strategi Penanaman Ideologi Pancasila Sebagai Solusi Terkikisnya Nasionalisme Melalui Pengemmbangan Model Pembelajaran Berorientasi Kompetensi Pendidikan Kewarganegaraan Perguruan Tinggi. Jurnal Ketahanan Nasional, XIX(2), 98-103.

Zam, M. (2018). Nasionalisme Indonesia dan Nasionalisme 4.0. Retrieved February 18, 2020, from https://www.kompasiana.com/ma ulanazam/5be50b6ac112fe682b37 a052/nasionalisme-indonesia-dannasionalisme-4-o? 